$\xi=-1$

\title{
A Sustainable Model for Heritage Property: an Integrative Conceptual Framework
}

\author{
Fatin Afiqah Md. Azmi ${ }^{1}$, Suriatini Ismail ${ }^{2}$, Rosdi Ab. Rahman ${ }^{3}$, Mohammad Tahir Sabit ${ }^{4}$, Junainah Mohammad ${ }^{5}$ \\ ${ }^{1,2}$ Faculty of Architecture and Ekistics, Universiti Malaysia Kelantan \\ ${ }^{3}$ University Malaysia Kelantan \\ ${ }^{4}$ Faculty of Technology and Business, Universiti Tun Hussein Onn Malaysia \\ ${ }^{5}$ Faculty of Architecture, Planning and Surveying, Universiti Teknologi MARA Perak \\ *Corresponding author E-mail: fatinafiqah87@gmail.com
}

\begin{abstract}
Malaysia is one of the developing countries but the management and investment by the local authority and investors in the heritage property remain limited which are apparent in the literature. Studying an integrative literature review is the most appropriate way to address the problem of heritage property. It is indicated that the local planning authorities do not have the financial capacity for providing incentives because the conservation and preservation works are costly. If the heritage property is neglected, deteriorated, and dilapidated, the value of archaic services may be affected. The objective of this paper is to review the heritage management system in Malacca and Penang, considering the institutional, legal, and resources frameworks and concerning on the heritage conservation, investment, and valuation. In this study, some variables have been obtained by database that can be used to evaluate the existing frameworks. Finally, all variables are summarized in a new sustainable model by identifying the gaps in the local literature. It is hoped that the present review would be considered as a kind of strategy for the future research and has made substantive contributions to the knowledge as well as inventing new thinking in the field of heritage property.
\end{abstract}

Keywords: Heritage Management System; Conservation; Investment; Valuation; Sustainable Model

\section{Introduction}

Heritage building can be defined as human creation which symbolises iconic building with local identity, cultural value, memorial events, and tourism-related business for a country. It is worth conserving and preserving as it represents something worth remembering about past that should be passed to future generations (1). In fact, the heritage is about the local identity and culture of local communities that could be a driver of sustainable development $(2,3)$. This is because integrating investment and conservation in the heritage property result in empowerment of community. Such approach will eventually cause income-generating, creating employment, reducing poverty, stimulating enterprise development by the poor, fostering private investment and leveraging additional resources (4). However, many conservation and preservation efforts are still in their infancy while most of the heritage properties are simply deteriorating due to the ageing process, natural causes and lack of proper planning consideration (5). Unfortunately, if a building is ancient and deteriorated, it would consequently affect its archaic services, and may harm its authenticity, which would contribute to the loss of its true value.

Malaysia is one of the developing countries, therefore, the management and investment by the local authority or investors in the heritage property remain limited. It is found that the local planning authorities do not have the financial capacity to provide incentives for the costly conservation and preservation works because the restoration and maintenance costs of the heritage property are almost millions $(6,7)$. One of remedies to this problem is thought to use tax money for conservation efforts; but in Malaysia, this is not the case due to limited revenue. Thus, one needs to increase taxes, attract social investors to directly or indirectly participate in the conservation of the heritage property through infrastructure development in the surrounding areas, as well as the region since investment acts as an important source of capital formation and stimulates the economic growth.

Investment has "success domino effect" as the more the region attracts investment, the more it grows. The more it grows, the more investors are willing to provide investment. The more investment flows into the country, the greater the economic chain reaction to sustain such growth. Indeed, the higher taxes and funds could be tapped for the conservation and preservation works and maintaining the value of heritage property. With the knowledge, skills and capability of the investors to invest and conserve the heritage property, sustainable development could be achieved. Another way to mitigate the problem of inadequacy of funds is to create incentives for owners to repair and restore their heritage properties. This can be addressed by ascertaining the effectiveness of the heritage management system.

The previous studies have proposed a variety of solutions but the question is whether or not the above solutions can be integrated. Thus, this study is carried out in attempts to fill the gap. This paper presents current views in an integrated manner, and assess the effectiveness of the current heritage management system used by local authorities and investors in Malacca and Penang with a view to enhance the heritage property value. A new model is also presented based on a set of variables relating to heritage property for its sustainability. In line with this, the paper consists of introduc- 
tion, research methodology, literature review, discussion, and conclusion.

\section{Research Methodology}

This paper attempts to propose an integrated model for heritage properties. To achieve the aim, the issue was studied in six steps. First, the authors prepared the guiding question; second, searching or sampling the literature review; third, data was collected from secondary sources through the means of bibliographic search and the authors' experience; fourth, critical analysis of the current views on the point with the technique of integrating, analysing and synthesising data in order to understand the issues relating to heritage property; fifth, discussion of results by means of a comparative method was chosen for cursory investigation of all variables related to heritage property; and finally, presentation of the integrative literature review whereby the outcome from the first until five steps have proposed a sustainable model for heritage property. For data gathering, all possible variables comprised of a set of legal, institutional, and resources frameworks, together with the relationship between heritage investment, heritage conservation, and heritage valuation were performed. To clarify their curren relationship, an analysis of texts on the history, theory, principles, concepts, and regulations of heritage property was undertaken This was to look at how the heritage management system, as well as the integration of heritage investment, heritage conservation, and heritage valuation are implemented and interpreted towards developing a sustainable model. They acted as a guide for creating a sustainable model for heritage property as a final product of this research. The outcome of the analysis is believed to meet the objective of this study.

\section{Literature Review}

This section presents and synthesizes the integrative literature review into variables related to heritage property. This part covers the issues of heritage property, heritage management system, conservation of heritage property, sustaining efforts for the sustainability of heritage property, investment in heritage property, importance and impact of sustaining and investing in heritage property, and valuation of heritage property.

Theoretically, there are three elements of a heritage management system namely institutional, legal, and resources frameworks (UNESCO, 2013). We follow the same theoretical background, and integrate views of various scholars relating to the above elements of heritage management system. While we intend to integrate and synthesise such views we will also show gaps and weaknesses of the given opinions.

\subsection{Financial Issues Relating to Heritage Property (Re- sources)}

Seven financial problems relating to heritage properties have been mentioned by the authors; namely: (1) lack of financial sources dedicated to heritage preservation; (2) lack of planning incentives; (3) lack of financial incentives, such as tax rebate, heritage valuation for local rates, land tax, and reduction of land premium; (4) lack of designation of heritage precincts (Hong Kong Planning Department, 2002); (5) scarcity of funds in local budget for investment; (6) low financial potential of local stakeholders; and (7) burdensome tax system. It is the inevitable need of the hour to seek funds from the private sector in the form of donation, and trust as well through revising national tax policy real estate tax credits, financial incentives in addition to the strategic planning level and the new initiatives $(2,3,7)$. These are merely views that do not go beyond that.

\subsection{Heritage Management System}

Heritage management system is a mechanism to deal with heritage property which is classified into legal, institutional, and resources frameworks. Institutional framework is derived either from the formal or informal legislations or any combination thereof. There exist many institutional frameworks today, for example: central government, semi-governmental, hybrid institutions, private trusts, private owners, public authorities, etc. Legal framework refers to an action of people and organizations, which is controlled by a mandate, usually in the form of legislation. It comprises of the constitution of heritage and its conservation and management criteria. Each framework, nevertheless, has its own dependant variables which are summarized in Table 1 and Figure 1 below. Overall, resources are crucial for creating operational capacity and facilitating process amongst human, financial, and intellectual inputs (UNESCO, 2013).

Legal frameworks affect the value of property and its marketability due to specific restrictions on renovation and building use, when it is protected under public policy $(8,9)$ (Nor'aini, 2007; Pickerill, 1997; Thersby, 2002). However, the Hong Kong Planning Department (2002) observed that through heritage policy, a holistic framework could be achieved by means of discharging duties by the government departments and a comprehensive strategy for declaration of heritage site. A comprehensive legal framework therefore needs to be in place.

At present so far, the states of Penang and Malacca have their own legislations. They are in the form of Enactment on Conservation and Restoration of Cultural Heritage in Melaka (1988) and Draft Guidelines for Conservation Areas and Heritage Buildings, Penang Georgetown. The local authorities in other states are depending on legal protection provided by the National Heritage Act (2005), and The Town and Country Planning Act (1976, amendments 1993, 1995, 2001).

The state body that is responsible to conserve and preserve the heritage property is Department of National Heritage under Ministry of Culture, Art, and Heritage, established pursuant to Section 8 of the National Heritage Act 2005. This provision provides the ease of conservation and preservation of national heritage, including intangible and tangible cultural heritage; be it the natural heritage, treasure trove, and other related matters. The UNESCO has listed two cultural and two natural World Heritage Sites in Malaysia. However, this paper covers the tangible heritage property, notably heritage buildings which are located in world heritage designated or protected areas of Penang and Malacca.

Effort is made to attract private investment. For example the Control of Rent Act 1966 has been repealed since 1997. This was thought to bring up high rental which could encourage owners and investors to restore the heritage buildings. However, this legislation has not given any incentive to the private owners of heritage buildings for maintaining their shop houses which could prevent any damage or decays that could lead to major structural defects. This may threaten the protection given to such buildings by United Nations Educational, Scientific and Cultural Organization (UNESCO). UNESCO has the power to remove heritage buildings from the list of world heritage sites if they detected any threat on it (10). Therefore, having more conservation and preservation activities are crucial to maintain the proclamation of Penang and Malacca as the UNESCO World Heritage Site.

The UNESCO protection has somehow changed the physical and cultural landscape of Penang and Malacca. For example, there were more changes in terms of the guidelines, legislations, principles, and town planning relating to conservation particularly involving heritage property in urban areas. To perpetuate the value of cultural heritage, majority of the heritage buildings should remain buildings that consist of traditional trades, represent traditional architecture, and show the influx of traditional designs, materials and elements inherited from one generation to another generation (Min et. al., 2012). However, most of traditional trades have been upgraded into tourism-related outlets or businesses, 
galleries, contemporary artisans, and so forth in the hope of increasing tourist visits to the heritage buildings. This situation may be beneficial for revitalizing the local economy, stabilizing the value of heritage property, attracting investment, and reducing obsolesces of heritage buildings. Nevertheless, these circumstances have led to uncontrolled development, regeneration of town centre, marginalization and displacement, reinforcement of local identity, restructuration of local economy (Nomination Dossier Historic Cities of the Straits of Malacca, 2008), and the pollution that affected the neighbouring residential and commercial areas. To sum up, designating a site as a protected heritage property is achieved through a legislative tool that can be used to help maintain a legacy for the future. Nonetheless, Legal and statutory protections are not sufficient for sustainable conservation and management of private and public heritage property. Other efforts should be added; otherwise, the state government could be viewed unsuccessful in utilizing heritage property to improve the socioeconomic well-being of the society. Efforts must be made to avoid the community members and heritage practitioners are not plagued with insufficient entrepreneurial skills (African World Heritage Fund, 2014), less promotion, use of improper techniques, lack of information and funding.

It is fundamental to mention that heritage property designation is expected to increase heritage funds as well as to assist heritage institutions to finance the development of heritage properties and provide substantial socio-economic project to the society. Hence, heritage management system, conservation should be the priority of the local authority and investors for sustaining the value of heritage property, as has been discussed below.

\subsection{Conservation of Heritage Property}

Under Section 2 of Malaysia National Heritage Act 2005 (Act 645), conservation is defined as restoration, rehabilitation, preservation, adaptation, and reconstruction or any mix thereof. The conservation under the Preservation and Conservation of Cultural Heritage Enactment (1988) and Malacca Enactment No. 6 (1988) are described as "a process of looking after a cultural heritage or a conservation area so as to retain its significance, including its maintenance, preservation, restoration, reconstruction, adaptation or a combination of two or more of these" (8). Conservation also includes preventing any decay and managing changes technically and it is not restricted to a site or a building.

Since there are escalating numbers of decay and neglect in heritage property in Malaysia, it is timely that conservation works are given priority. For this, all variables related to heritage conservation have to be investigated, namely conservation management plan, conservation awareness, preservation and restoration, adaptive reuse and building, conservation zone, conservation doctrines, incentives, local community participation, and land use planning development, as illustrated in Figure 1.

However, conservation is seen less important in the developing countries if compared to other urban property developments. One of the reasons is, conservation is frequently thought to be a constraint to the development of real estate in term of financial capacity, climate changes, and enforcement. These mind set has to change; as attention should be paid to the positive impact of conservation, which are broad and capable to positively contribute to the sustainability of economic, social, cultural and environmental spheres. In achieving these targets, sustaining efforts by the local authority and investors should be highlighted as mentioned below.

\subsection{Sustaining Efforts for the Sustainability of Heritage Property}

Historical Malacca City Council, known as Majlis Bandaraya Melaka Bersejarah (MBMB), recently has established a Conservation Unit and Municipal Conservation Committee, which are commendable. However, the Council is constrained by the lack of financial resources. Due to limited resources, tourism is seen very important to the local economy. It should be noted that for restoration and conservation efforts the Federal Government through the Department of Museums and Antiquities helps the local authorities, however this assistance is for conservation of public buildings only. For private properties, the local planning authority does not have the financial capacity to carry out large scale area conservation projects nor is it in the position to create incentives for owners to repair and restore their buildings. For this reason, the Department of Local Government in the Ministry of Housing and Local Government has been trying very hard to convince the Federal Government to apportion half of the income collected through the sales and service tax to local authorities.

Though two action plans were completed which included some form of visitor management strategies (MPMBB/UTM, 2002; JICA/MPMBB, 2002), the proposals did not specifically recommend a revenue capture mechanism which would ensure that part of the income from tourism could be reinvested into building or area conservation. Such mechanism is already in place in historic cities such as Hoi An, Vietnam (voucher system) and Bhaktaphur, Nepal (entrance fee). In the case of Malaysia, direct taxation from tourism in the form of the $10 \%$ sales tax and 5\% service tax are directly channelled to the Federal Government's coffers given that tourism is a Federal affair and responsibility. The only direct income from tourism that the Melaka State government is allowed to collect is the entrance fee to the 15 museums managed by the Melaka Museums Corporation (PERZIM). However, such income enabled the state to fund the establishment of mini museums or galleries.

Experience in other countries like Australia, Canada, Norway, Romania, Singapore, United Kingdom, and United States of America has shown that heritage property typically produces numerous benefits and positive results $(3,9,11)$. In Malaysian context, how much benefits could be obtained by Malaysia is not known yet. Positive steps are taken thus far which includes the transformation plan, titled Transformasi Nasional 2050 (TN50 ${ }^{1}$ ), and the introduction of good process in improving the management mechanism for conservation, by state government and local authority.

The efforts by local authority can be summarized as follows: (1) improving the legal frameworks i.e.: Melaka Structure Plan (Review) 2002, Action Plan for Conservation within Melaka Historic City (2002), Action Plan for Cultural Tourism; (2) establishment of conservation committee i.e.: NGOs such as the Melaka Heritage Trust (MHT); (3) establishment of conservation unit for public sector, private sector, and private owners, within local authority; (4) funding of restoration projects, provided by the Local Government and Ministry of Housing; (5) public education programmes like the Local Agenda 21 for the Historic Inner City, public participation workshops, and public dialogs; (6) documentation exercise to record data such as building inventories, demographics, socio-economic profile of local residents, and details of vernacular architecture. Since there are formal policy and legal frameworks provided, they could guide the investors on the status of historic building, and provides an economic return. This may encourage the investors to partake in the sustainability of heritage properties. The relevant variables related to heritage investment for heritage property are explored below.

\subsection{Investment of Heritage Property}

Pursuant to Said et. al. (2013), the concept of sustainable heritageled regeneration involves six variables for heritage investment and sustaining conservation. They are: property, land, capital, human resources and political aspects. For the purpose of investment in heritage properties the significant variable includes: policy incentives, location, funds from taxation, profits of infrastructure development, high return on capital, market size and number of popula- 
tion, human and heritage resources, political and economic stability. Where the above conditions are available the chance for investment should not be missed; for conserving the heritage property represents the physical image of the historic city, and townscape value that consists of the changing of culture and trading material. These are explained below.

\subsection{Importance and Impact of Sustaining and Investing in Heritage Property}

Previous studies have identified the significance of World Heritage Site as a catalyst that can: (1) attract investment; (2) additional fund; (3) encourage learning and education process; (4) ensure proper conservation; (5) create collaborative working; (6) instill civic pride; (7) develop social capital (Patricia, 2013). Related or additional benefits are thought that it can (8) sustain the economic, social and environmental activities; (9) understand the heritage interpretation and valuing; (10) enhance domestic and international tourism; (11) support new small business and creative industries; (12) generate a social network and entrepreneurial innovation (Valentina et. al., 2015); which can (13) stimulate local and regional economies (Khairul, 2013). Furthermore, it is assumed to act as a magnet for inward investment, because employees may wish to live near such places and public may identify such places with quality and good service (www.hha.org.uk). An investment in heritage property may give special heritage identity that may help in the survival and sustainability of the business; it may also transform local development being switched to local activities, tourism or hospitality industry due to restructured economy and privatization that in turn may affect the economic growth (3).

To be more specific, investing in heritage property has wider benefits. It can (1) create local jobs opportunities; (2) help the development of corresponding skills e.g. traditional skills, rituals, and cultural customs (Thorsby, 2012); (3) transform areas or cities physically, through the improvement of buildings which in turn can increase local attractiveness and generate significant returns on investments (11). Investment in heritage properties can also bring (4) more business (Nor'aini et. al., 2007) through improvements of amenities (9) or entrepreneurship, (5) youth involvement (3), (6) education e.g. understanding of architectural, archaeological significance, and scientific values (9), (7) recreation of more varied and enjoyable public realm (www.hha.org.uk), (8) source of capital formation, (9) transferring of technology, and (10) increase of export competitiveness (12). Additionally, in relation to return on investment in heritage property, it is to be noted that the impact of conservation of heritage property, in property market, can be measured based the property values levels, in the conservation areas (8). Hence, we discuss the existing method to measure the value of heritage property in the following section.

\subsection{Valuation of Heritage Property and its Variables}

Bakri, Ibrahim, Ahmad, \& Zaman (13) found that the method used in valuing heritage property is divided into two: (a) conventional method and (b) advanced method. Three conventional methods are used to obtain the value of heritage property, that is sale comparison, cost, and income capitalization but these methods have their own weaknesses compared to the advanced method. There are two main approaches derived from the advanced method to measure the value of heritage property specifically in the protected conservation areas namely Stated Preferences (SP) and Revealed Preferences (RP) methods. SP method consists of choice modeling and contingent valuation method (CVM). On the contrary, RP method includes travel cost method and hedonic pricing model. The hedonic pricing model was developed further and came out with two methods namely Ordinary Least Squares (OLS) and Rank Transformation Regression (RTR). At present so far, there is no effective approach or tool used by the evaluator to obtain the approximate value of heritage property that can be applied further in valu- ing the impact of sustaining the heritage property. Nonetheless, the academician like believes that CVM and RTR have complimented the criteria of determinants of an effective, reliable, valid, and practical approach of valuation for heritage property.

Since valuation is a critical stage in the activities that relate to conservation, preservation and maintenance works, the list of variables related to heritage property valuation should be considered by decision maker. Such variables include (1) transaction-related (freehold or leasehold title, ownership of land either private or government, sell condition, year of transaction); (2) structural (lot size, floor area, rooms, building age, construction period, busy street, proportion of water areas, population density, percentage ethnic, distance to centre, roof types, building and roof material, maintenance); (3) historical (ensemble, architectural style, authenticity, facade types); (4) legal (Local Government Act 1976, Malaysian Valuation Standard 2015, MPSAS 17, IPSAS 17, International Valuation Standards 2011, Accounting Standards BoardHeritage Assets GRAP 103); (5) spatial (monument density, monument dummy, distance to town city, zoning, neighbourhood quality); and (6) location (street name) characteristics as been provided in Figure 1.

\section{Results and Findings}

There are three main variables related to heritage management system namely legal, institutional, and resources frameworks. These variables were supported by the integration of another three fundamental elements including heritage conservation, heritage valuation, and heritage investment. The combination of all variables is complementing each other. This means that the enforcement of legal framework is safeguarding the heritage conservation activities, while the establishment of institutional framework is monitoring the heritage investment process, as well as the resources framework is perpetuating the heritage property value. The results and findings are based on the author's initial investigation as shown in Table 1. By analysing all variables related to heritage property, the results of analysis are considered as reliable, and further be used for developing a new model known as a Sustainable Model for Heritage Property as depicted in Figure 1. It is hoped that the future studies will use this model, and its variables related to heritage property and show their functions.

Table 1: Lists of Variables Related to Heritage Management System $(1966-2010)$

\begin{tabular}{|c|c|c|c|}
\hline Year & \begin{tabular}{|ll} 
(A) Heritage Related to Le- \\
gal Framework
\end{tabular} & Malacca & Penang \\
\hline 1966 & Repeal of Control of Rent Act (363) & $\sqrt{ }$ & $\sqrt{ }$ \\
\hline 1968 & $\begin{array}{l}\text { Rules relating to investment Incen- } \\
\text { tive }\end{array}$ & $\sqrt{ }$ & \\
\hline 1970 & $\begin{array}{l}\text { Integration of conservation in Master } \\
\text { Plan }\end{array}$ & & $\sqrt{ }$ \\
\hline 1974 & $\begin{array}{l}\text { Integration of conservation in Inter- } \\
\text { im Zoning Plans } 1 / 73\end{array}$ & & $\sqrt{ }$ \\
\hline 1976 & $\begin{array}{l}\text { Integration of conservation in Town } \\
\text { and Country Planning Act (172) }\end{array}$ & $\sqrt{ }$ & $\sqrt{ }$ \\
\hline 1976 & $\begin{array}{l}\text { Integration of conservation in Local } \\
\text { Government Act (171) }\end{array}$ & $\sqrt{ }$ & $\sqrt{ }$ \\
\hline 1976 & $\begin{array}{l}\text { Integration of conservation in Antiq- } \\
\text { uities Act (168) }\end{array}$ & $\sqrt{ }$ & $\sqrt{ }$ \\
\hline 1979 & Conservation Area identified & $\sqrt{ }$ & \\
\hline 1984 & $\begin{array}{l}\text { Integration of conservation in Struc- } \\
\text { ture Plan (urban form, townscape, } \\
\text { landscape) }\end{array}$ & & $\sqrt{ }$ \\
\hline 1985 & Conservation Area upgraded & $\sqrt{ }$ & \\
\hline 1987 & $\begin{array}{l}\text { Guidelines for five conservation } \\
\text { zones in inner city are implemented }\end{array}$ & & $\sqrt{ }$ \\
\hline \multirow[t]{2}{*}{1988} & Heritage zone designation & $\sqrt{ }$ & \\
\hline & $\begin{array}{l}\text { Integration of conservation in } \\
\text { Preservation and Conservation Cul- } \\
\text { tural Heritage Act established }\end{array}$ & $\sqrt{ }$ & \\
\hline 1989 & $\begin{array}{l}\text { Integration of conservation in } \mathrm{Pe}- \\
\text { nang State Structure Plan }\end{array}$ & & $\sqrt{ }$ \\
\hline
\end{tabular}




\begin{tabular}{|c|c|c|c|}
\hline 1990 & $\begin{array}{l}\text { Integration of conservation in MPPP } \\
\text { Draft Structure Plan }\end{array}$ & & $\sqrt{ }$ \\
\hline 1991 & $\begin{array}{l}\text { Integration of conservation in } 21^{\text {st }} \\
\text { Century Penang Strategic Develop- } \\
\text { ment Plan (1991-2000) }\end{array}$ & & $\sqrt{ }$ \\
\hline \multirow[t]{4}{*}{1993} & $\begin{array}{l}\text { Integration of conservation in Guide- } \\
\text { lines on Planning Controls around } \\
\text { Georgetown }\end{array}$ & & $\sqrt{ }$ \\
\hline & $\begin{array}{l}\text { Integration of conservation in Struc- } \\
\text { ture Plan }\end{array}$ & $\sqrt{ }$ & \\
\hline & $\begin{array}{l}\text { Integration of conservation in De- } \\
\text { velopment Plan }\end{array}$ & $\sqrt{ }$ & \\
\hline & $\begin{array}{l}\text { The amendment of Town and Coun- } \\
\text { try Planning Act }\end{array}$ & $\sqrt{ }$ & \\
\hline 1994 & Conservation Action Area Plan & $\sqrt{ }$ & \\
\hline 1995 & $\begin{array}{l}\text { The amendment of Town and Coun- } \\
\text { try Planning Act }\end{array}$ & & $\sqrt{ }$ \\
\hline 1996 & $\begin{array}{l}\text { Heritage Conservation Policy, de- } \\
\text { velopment control and planning for } \\
\text { Georgetown by MPPP }\end{array}$ & & $\sqrt{ }$ \\
\hline 1997 & Repeal of Rent Control Act (572) & $\sqrt{ }$ & $\sqrt{ }$ \\
\hline 1998 & $\begin{array}{l}\text { The amendment of MPPP Survey of } \\
\text { Report for Draft Structure Plan }\end{array}$ & & $\sqrt{ }$ \\
\hline 2000 & $\begin{array}{l}\text { The amendment of MPPP Draft } \\
\text { Structure Plan }\end{array}$ & & $\sqrt{ }$ \\
\hline \multirow[t]{4}{*}{2001} & $\begin{array}{l}\text { The study on the Improvement and } \\
\text { Conservation of Historical Urban } \\
\text { Environment }\end{array}$ & $\sqrt{ }$ & \\
\hline & $\begin{array}{l}\text { Integration of conservation in Local } \\
\text { Plan }\end{array}$ & $\sqrt{ }$ & \\
\hline & $\begin{array}{l}\text { The amendment of Town and Coun- } \\
\text { try Planning Act }\end{array}$ & $\sqrt{ }$ & $\sqrt{ }$ \\
\hline & $\begin{array}{l}\text { Integration of conservation in Se- } \\
\text { cond Penang Strategic Development } \\
\text { Plan (2001-2010) }\end{array}$ & & $\sqrt{ }$ \\
\hline \multirow[t]{6}{*}{2002} & $\begin{array}{l}\text { The urban Conservation Guidelines } \\
\text { for Historic City of Melaka Munici- } \\
\text { pal Council's Conservation Zone }\end{array}$ & $\sqrt{ }$ & \\
\hline & $\begin{array}{l}\text { Integration of conservation in } \\
\text { Melaka Structure Plan (Review) to } \\
\text { designate Special Area }\end{array}$ & $\sqrt{ }$ & \\
\hline & $\begin{array}{l}\text { Melaka River Rehabilitation, Im- } \\
\text { provement and Conservation of } \\
\text { Historic Urban Environment }\end{array}$ & $\sqrt{ }$ & \\
\hline & $\begin{array}{l}\text { Action Plan for Conservation Within } \\
\text { Melaka Historic City }\end{array}$ & $\sqrt{ }$ & \\
\hline & Action Plan for Cultural Tourism & $\sqrt{ }$ & \\
\hline & $\begin{array}{l}\text { The Study of the Improvement of } \\
\text { Conservation in the Historical City } \\
\text { of Melaka }\end{array}$ & $\sqrt{ }$ & \\
\hline 2003 & $\begin{array}{l}\text { Integration of conservation in Con- } \\
\text { servation Zones downsize to } 188.64 \\
\text { ha }\end{array}$ & $\sqrt{ }$ & \\
\hline 2004 & $\begin{array}{l}\text { Lifting of the freeze on development } \\
\text { control in conservation zones }\end{array}$ & $\sqrt{ }$ & \\
\hline \multirow[t]{3}{*}{2005} & National Heritage Act (645) & $\sqrt{ }$ & $\sqrt{ }$ \\
\hline & $\begin{array}{l}\text { Integration of conservation in Draft } \\
\text { Structure Penang }(2005-2020)\end{array}$ & & $\sqrt{ }$ \\
\hline & $\begin{array}{l}\text { An Interim Conservation Zone: } \\
\text { reduced in size (193 hectares core } \\
\text { heritage zone to } 99 \text { hectares; } 246 \\
\text { hectares buffer zone to } 89 \text { hectares) }\end{array}$ & & $\sqrt{ }$ \\
\hline 2006 & Historic Area Action Plan & $\sqrt{ }$ & \\
\hline 2007 & $\begin{array}{l}\text { State Structure Plan: George Town } \\
\text { Heritage Preservation Area }\end{array}$ & & $\sqrt{ }$ \\
\hline 2010 & $\begin{array}{l}\text { Special Area Plan: The Conservation } \\
\text { Area Management Plan of Melaka } \\
\text { Historic City }\end{array}$ & $\sqrt{ }$ & \\
\hline Year & $\begin{array}{l}\text { (B) Heritage Related to In- } \\
\text { stitutional Framework }\end{array}$ & Malacca & Penang \\
\hline 1969 & $\begin{array}{l}\text { Malaysian NGOs (Consumers Asso- } \\
\text { ciation of Penang) created }\end{array}$ & & $\sqrt{ }$ \\
\hline 1970 & $\begin{array}{l}\text { Malaysian NGOs (Community Insti- } \\
\text { tute) created }\end{array}$ & & $\sqrt{ }$ \\
\hline 1977 & Malaysian NGOs (Aliran) created & & $\sqrt{ }$ \\
\hline
\end{tabular}

\begin{tabular}{|c|c|c|c|}
\hline & Malaysian Friends of Nature & & $\sqrt{ }$ \\
\hline 1983 & Malaysian Heritage Trust created & $\sqrt{ }$ & $\sqrt{ }$ \\
\hline 1985 & Penang Heritage Trust created & & $\sqrt{ }$ \\
\hline 1990 & Friends of Penang Hill & & $\sqrt{ }$ \\
\hline \multirow[t]{2}{*}{1994} & $\begin{array}{l}\text { City } 101 \text { Museums set up by State } \\
\text { Government }\end{array}$ & $\sqrt{ }$ & \\
\hline & $\begin{array}{lll}\text { Melaka } & \text { Museums } & \text { Corporation } \\
\text { (PERZIM) established } & \end{array}$ & $\sqrt{ }$ & \\
\hline 1999 & Melaka Heritage Trust created & $\sqrt{ }$ & \\
\hline 2004 & $\begin{array}{l}\text { Ministry of Culture, Arts and Herit- } \\
\text { age created }\end{array}$ & $\sqrt{ }$ & $\sqrt{ }$ \\
\hline Year & $\begin{array}{ll}\text { (C) Heritage Related Re- } \\
\text { sources Framework }\end{array}$ & Malacca & Penang \\
\hline- & $\begin{array}{l}\text { Tax allocation (Apportion half of the } \\
\text { income collected through the } 10 \% \\
\text { sales tax and 5\% service tax to local } \\
\text { authorities). }\end{array}$ & $\sqrt{ }$ & \\
\hline 1974 & $\begin{array}{l}\text { Funding project by the Federal gov- } \\
\text { ernment: success of the Komplex } \\
\text { Tun Abdul Razak's tower (KOM- } \\
\text { TAR) which is estimated to cost } 550 \\
\text { million dollar. }\end{array}$ & & $\sqrt{ }$ \\
\hline 1993 & Conservation Trust Fund Formed. & $\sqrt{ }$ & \\
\hline 1996 & $\begin{array}{l}\text { Funding project by the Federal and } \\
\text { State government (success of the } \\
\text { Campbell Street project after } 10 \\
\text { years). }\end{array}$ & & $\sqrt{ }$ \\
\hline 1999 & $\begin{array}{l}\text { Incentive Programme for Conserva- } \\
\text { tion by MPPP. }\end{array}$ & & $\sqrt{ }$ \\
\hline \multirow[t]{3}{*}{2001} & $\begin{array}{l}\text { Conservation Trust Fund used to } \\
\text { finance selected building conserva- } \\
\text { tion project. }\end{array}$ & $\sqrt{ }$ & \\
\hline & $\begin{array}{l}\text { Local Agenda } 21 \text { for the Historic } \\
\text { Inner City, public participation } \\
\text { workshop, and public dialogs. }\end{array}$ & $\sqrt{ }$ & \\
\hline & $\begin{array}{l}\text { Documentation exercise (building } \\
\text { and traditional trade inventories, } \\
\text { demographic, socio-economic pro- } \\
\text { file of local residents, and details of } \\
\text { vernacular architecture). }\end{array}$ & $\sqrt{ }$ & \\
\hline 2002 & $\begin{array}{l}\text { Revenue Capture Mechanism (En- } \\
\text { trance fee to the } 15 \text { museums) }\end{array}$ & $\sqrt{ }$ & \\
\hline 2008 & $\begin{array}{l}\text { Major conservation of derelict } \\
\text { shophouses in George Town, valued } \\
\text { at RM } 100,000 \text {. }\end{array}$ & & $\sqrt{ }$ \\
\hline 2009 & $\begin{array}{l}\text { Allocation of RM } 30 \text { million for } \\
\text { conservation and protection of his- } \\
\text { toric buildings by the Ministry of } \\
\text { Information, Communication and } \\
\text { Culture. }\end{array}$ & $\sqrt{ }$ & \\
\hline
\end{tabular}

The current heritage management system in Malacca and Penang seems effective and adequate in term of legal and institutional frameworks to sustain the heritage property, but it is ineffective and inadequate in the sense of resources framework. The local authority acts as law enforcement agencies and clearly demonstrated determination in safeguarding the heritage property (ICOMOS, 2008) through policies, zoning, and others. Nonetheless, the allocation of fund for the conservation and preservation works in heritage property by local authority is still in infancy stage as the last project funding was in year 2009. As stipulated under Investment Incentive Act 1968 which is effective for Malacca Historical Cities and the Malaysia National Heritage Act 2005 (Act 645), government provides incentives or levy for investing in heritage property. It is hoped that, the formulation of policies for heritage property may have encouraged investors to invest in heritagedesignated properties. Having a formal policy gives investors clear guidelines regarding the status of the building and creates expectations for some economic returns from the historic building or from related activities that may be conducted in its vicinity. Indeed, successful repair of historic buildings usually attracts a higher value to that building and will generally attract further investment to the area and it is a merit in creating a robust and successful framework for further development (14). 


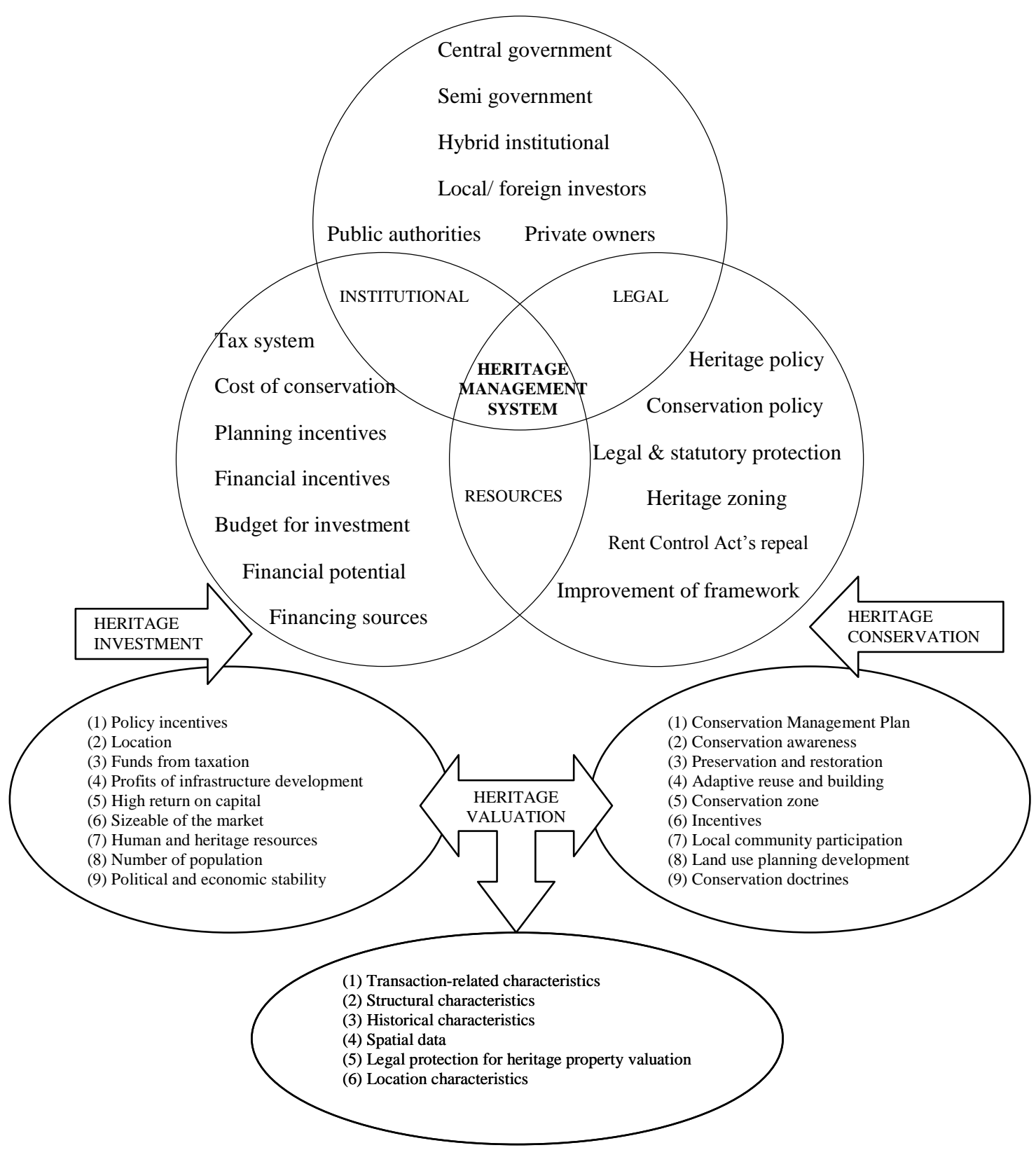

Fig. 1: A Sustainable Model for Heritage Property

In spite of the above heritage management system in Malacca and Penang, the innovative preventive measures (such as the repeal of Rent Control Act (363) that gives incentive to the owners of heritage buildings to demolish the pre-war shophouses, attracting various stakeholders in heritage conservation programme at international, national, and local level, and enhancing the additional financial resources for heritage conservation purpose) adopted by them have either failed or need further review. This failure could be because not all or the right solution of obtaining funds to provide incentives for heritage property was identified. The authors suggest an alternative process that may attract investment in the heritage property and surrounding areas to increase tax revenues of the state. Besides, financial institution should provide loans and/or grants to property owners or groups undertaking restoration or rehabilitation of designated heritage property. Other forms of financial assistance should be investigated, developed, and utilized wherever appropriate. These kinds of alternative process needs more attention and further discussion, to sustain the historical value of the heritage property.

\section{Conclusion}

To date, previous studies have proposed several solutions offered by the local planning authorities, variety of local institutions, and investors for giving fund to conserve and preserve the heritage 
property with the goal to sustain or enhance the value of heritage property. This would imply by providing resources inter alia, tax system, cost of conservation, planning incentives, financial incentives, budget for investment, financial potential, and financing sources as been illustrated in Figure 1. Another way to mitigate the problem of inadequacy of funds is to create incentives for owners to repair and restore their heritage properties. However, this effort is immaterial because the conservation and preservation works reach millions. This can be addressed by ascertaining the effectiveness of the heritage management system. Overall, the existing heritage management system is effective by means of legal and institutional frameworks, but ineffective in term of resources framework as been explained previously. To remedy this problem, the designation of World Heritage Site is deemed to give a positive impact.

After the proclamation of the World Heritage Site status, several new developments have been proposed and investment in heritage sectors has also increased significantly. This progress is viewed as an important achievement for Malacca and Penang. With the knowledge, skills and capability of the investors to invest and conserve the heritage property, sustainable development could be achieved. Nevertheless, a sustainable approach would lead to failure in the absence of integration of the heritage management system, including legal, institutional, and resources frameworks, with the collaborative elements derived from heritage conservation, valuation, and investment. Therefore, a sustainable model for heritage property is needed as a guideline or cornerstone to ensure the sustainability of heritage property in both historical cities.

Where compliance to an integrative model is made, heritage can be considered as a unique property that may attract a value greater than its market price. Hence, it should be viewed a unique property market product, which can provide a new investment opportunity to the local authority and investors. This will benefit the owners of heritage property, state governments, tourists or visitors, and investors as well as federal government. It can become an engine of income generation by government and revenue resource in the form of taxes or structural funds, donation, contribution or trust. It may need revision of national tax policy, real estate tax credits, financial incentives, et cetera which need to be reinvested in the heritage property. In the process of reinvestment, fixed asset would be bought. This fixed asset would not be subject to restriction imposed on the heritage property particularly the existing legal, institutional, and resources frameworks. The income obtained from local authority or investors can be reinvested to help conserve and give new life to the local cultural revitalisation.

\section{Acknowledgement}

The authors gratefully acknowledge and extend their special thanks to Zamalah Post Doctoral Scheme at Universiti Malaysia Kelantan (UMK) and FRGS Project (R/FRGS/A02.00/0082A/002/2016/000371) for funding this research.

\section{References}

[1] Bin Hasbollah H. A theoretical framework for conserving cultural values of heritage buildings in Malaysia from the perspective of facilities management: University of Salford; 2014.

[2] OCDE O. OECD Tourism trends and policies 2014: OECD Publishing; 2014.

[3] Valentina V, Marius-Răzvan S, Stroe A. Innovative valuing of the cultural heritage assets. Economic implication on local employability, small entrepreneurship development and social inclusion. Procedia-Social and Behavioral Sciences. 2015;188:16 26.

[4] Cernea MM. Cultural heritage and development: a framework for action in the Middle East and North Africa: The World Bank; 2001.
[5] Toong YS, Utaberta N, editors. Heritage Buildings Conservation Issues of Shophouses in Kuala Lumpur Chinatown. Applied Mechanics and Materials; 2015: Trans Tech Publ.

[6] Kamal KS, AbWahab L, Ahmad AG. Pilot survey on the conservation of historical buildings in Malaysia. 2008

[7] Pickerill T, Pickard R. Real estate tax credits and other incentives for investing in historic property in the United States. RICS Foundation Research paper series. 2002;4(17).

[8] Yusof NA, Mui LY, Meng LL, Fern TS. Urban conservation as a development strategy to revitalize real estate market: an analysis of property transactions in Georgetown Penang. Journal of Construction in Developing Countries. 2007;12(2):43-61.

[9] Throsby D. Cultural capital and sustainability concepts in the economics of cultural heritage. 2002

[10] Mohd-Isa A, Zainal-Abidin Z, Hashim A. Built heritage maintenance: a Malaysian perspectives. Procedia Engineering. 2011;20:213-21.

[11] Pickard R. Funding the architectural heritage: A guide to policies and examples: Council of Europe; 2009.

[12] Mwilima N. Foreign direct investment in Africa. Social Observatory Pilot Project, Final Draft Report for the Labour Resource and Research Institute. 2003:29-45.

[13] Bakri AF, Ibrahim N, Ahmad SS, Zaman NQ. Valuing Built Cultural Heritage in a Malaysian Urban Context. Procedia-Social and Behavioral Sciences. 2015;170:381-9.

[14] Said S, Zainal SS, Thomas M, Goodey B. Sustaining old historic cities through heritage-led regeneration. WIT Transactions on Ecology and the Environment. 2013;179:267-78. 